\author{
CHAPTER FOUR
}

\title{
Intervention in Egypt
}

Intervention in Egypt contrasted dramatically with recent campaigns in Africa and Afghanistan. It involved the largest expeditionary force despatched by Britain since the Crimean War and achieved a decisive outcome in less than two months, that is, from the passing of a vote of credit by the House of Commons for an expeditionary force (27 July 1882 ) to the crushing victory at Tel-el-Kebir (13 September) and Wolseley's entry into Cairo (15 September 1882). The campaign avoided any embarrassing reverses like Isandlwana, Maiwand (27 July 1880) or Majuba, and reflected impressive co-operation between the armed services (with the navy assisting in the transportation of 35,000 men to the Egyptian theatre, deploying Marines and a 565-strong Naval Brigade as direct support, seizing the Suez Canal, transporting supplies along the Sweetwater Canal, and providing fire support from Gatling machine-guns, artillery and an armoured train). ${ }^{1}$ Many soldiers used the new Army Post Office Corps to send letters home, describing their 'baptisms of fire', the rigours of campaigning in Egypt, the battle of Telel-Kebir, and the reporting of their achievements. When such letters were passed on to newspapers, they often embellished reports from special correspondents which were censored for the first time. Although Emery quoted from nineteen letters in his account of the campaign, there were many more (and at least that number from the Black Watch alone). ${ }^{2}$ This chapter relies primarily, if not exclusively, upon previously unused correspondence.

The intervention was a response to the growth of the nationalist movement in Egypt under the military leadership of Arabi Pasha, the Egyptian minister of war, and its burgeoning hostility towards European control over Khedive Tewfik's Government and its finances. This hostility reached a crescendo when riots erupted in Alexandria (11 June 1882), involving the so-called 'massacre of Christians' and the flight of many Europeans. As these activities seemed to vindicate the alarmist 
reports of Sir Edward Malet, the British consul-general in Cairo, and Sir Auckland Colvin, who along with his French colleague was responsible for Egypt's 'financial credit', Gladstone's cabinet authorised military intervention to restore order in Egypt. ${ }^{3}$ Several weeks of planning ensued. A naval bombardment of Arabi's fortresses at Alexandria on 12 July confirmed that military resistance was likely and that a substantial force under Wolseley would have to be sent ashore. ${ }^{4}$ Meanwhile the reluctance of the Porte or France to support intervention ensured that this would be an exclusively British affair. The entire First Class Army Reserve (11,600 men) was called out (contrary to Cardwell's expectation that it would be employed only in a national emergency) and forces were despatched from England, the Mediterranean garrisons and India. As early as 3 July Wolseley intimated that he planned to advance on Cairo along the Sweetwater Canal from Ismailia, a route 45 miles shorter than that from Alexandria. He hoped to deceive Arabi by ini-

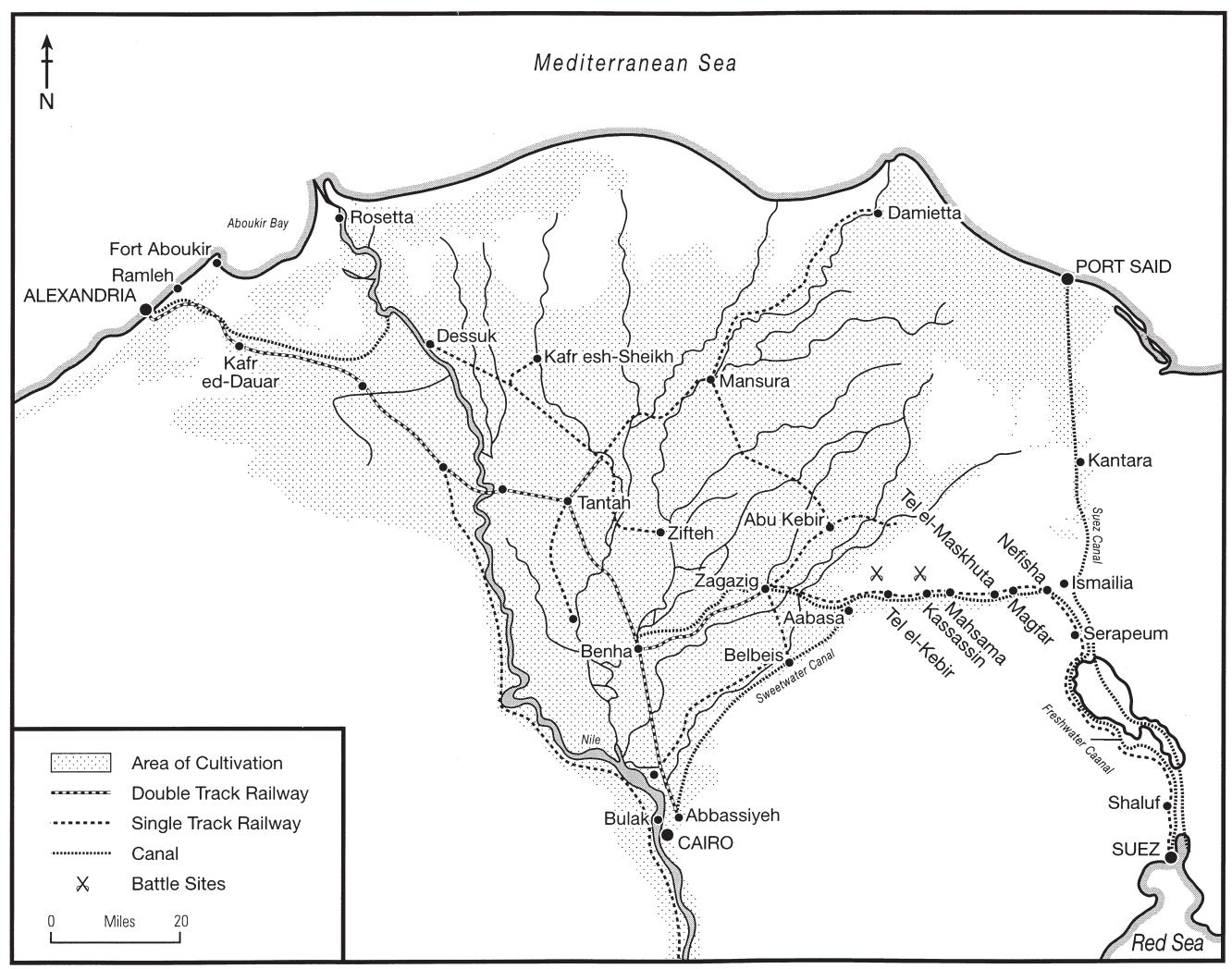

4 Intervention in Egypt, 1882 
tially deploying forces near Alexandria and by conducting active operations in that vicinity. ${ }^{5}$

Egypt was a convenient theatre for British forces - only a twelve-day sail from Britain and a much shorter one from Gibraltar or Aden. Advanced units under Sir Archibald Alison arrived in Alexandria on 17 July and others soon followed. Forces based in Britain left to rapturous send-offs: when the 1/Black Watch, as Bandsman A. V. Barwood recalled, travelled by train from Edinburgh to London, 'people, knowing we were going to war, turned out in great numbers at every station to cheer us ${ }^{6}{ }^{6}$ Even larger crowds gathered in London for the departure of the Guards, thronging the route from their barracks to the point of embarkation (Westminster Bridge Pier), whereupon 'the cheering was deafening', wrote Private Macaulay ( $1 /$ Scots Guards), 'as we passed down the river'. ' While the Seaforths endured 'a very rough sail' from Aden, the Black Watch, in Private Lauchlan McLean's opinion, enjoyed a 'delightful' voyage, with reasonable liberty, books, papers and evening concerts, 'more like an excursion party than anything else'. However rough or long the voyage, soldiers had to adapt rapidly to Egyptian conditions, a more daunting experience for soldiers coming directly from Britain. 'In passing through Alexandria', added McLean, 'the heat was something fearful, the sand about six inches deep, and the dust so thick that we could not see three paces in front of us'. 9

Soldiers were observant, nonetheless, as they moved through Alexandria and camped near Ramleh. Private George Snape, having seen Alexandria prior to the naval bombardment, now described how the 'forts, houses, shops, and public buildings in some parts were a mass of ruins - something dreadful to look $\mathrm{at}^{\prime} \cdot{ }^{10}$ Macaulay, like others, could distinguish between collateral damage from the naval bombardment and the pillaging of houses at Ramleh by Arabi's followers. Private $\mathrm{W}$. Bond (1/South Staffordshires) was appalled by the way Arabi and his army 'had plundered and ravished all he came across', while McLean added: 'Arabi's vermin destroyed everything they could not take away. ${ }^{11}$ After several minor engagements near Ramleh, British soldiers formed a very low opinion of the enemy's military capacity. 'Arabi Pacha [sic]', noted Snape, 'has plenty of men, but they are not up to much;' while another Marine observed: 'The Arabs are very poor marksmen, or else they could have killed every man in my company, for it advanced across a plain as open as any man could be exposed, and there was not one single man wounded all through the fight. ${ }^{12}$

Private S. Smith (1/South Staffordshires) described some of the early fighting near Ramleh:

There are only two regiments here, us and the 60th Rifles, and we have our work cut out, I can tell you. We are on some duty from morning till 
night, and every third night all night doing outlying picket and outpost duty, which is very hazardous work, as we are being fired upon continually. My company ... have had a regular battle with the enemy's outposts, but none of our side were injured; besides which we had one pitched battle with the main body, which lasted about two hours and a half. We were outnumbered fearfully, but eventually succeeded in driving them off. Their bullets ... were all too high, otherwise the slaughter must have been terrible indeed. As it was we had four killed and twenty-seven wounded, some of whom have since died.

He added perceptively: 'Arabi Pasha is not our only enemy out here. We have another formidable enemy in the shape of the heat, which is cruel, especially when you have to go out trench digging with arms and 70 rounds of ball cartridge. ${ }^{\prime 3}$

Alison's mission was to convince Arabi that the troops in and around Alexandria were preparing to attack his entrenchments at Kafr ed-Dauar and then move on to Cairo. Hence he periodically launched forays along the railway line and its adjacent canal, utilising the armoured train with skirmishing columns in support. On 5 August the mounted infantry advanced, as recounted by one of its number, Private Bond, with the infantry in the rear and the Naval Brigade on the right:

When near his stronghold, his cavalry met us and the battle commenced. We were only thirty-seven strong, but not a flinch. We exchanged a few shots, then the Infantry joined us ... We continued fighting until, with his heavy losses and his entrenchments taken, he retired ... out of our small band of 37 , we had lost one officer killed, one private killed, and three wounded. The Naval Brigade lost a few, also the Marines. ${ }^{14}$

For many soldiers, these minor engagements constituted their baptism of fire. Sergeant John Philip (2/Duke of Cornwall's Light Infantry) subsequently recalled their feeling of 'trepidation' as the DCLI advanced through the Egyptian shellfire: men had 'quivering lips and firm-set teeth' and uttered the occasional 'forced' laugh as shells flew harmlessly overhead. The 'Dukes' were relieved when the Naval Brigade returned 'the compliment from their guns on the train' and even more so when they themselves opened fire: in the place of 'nervousness ... came a fierce desire to push on, and close with the enemy ${ }^{\prime}{ }^{15}$ The 1/Gordon Highlanders had similar experiences on 20 August when engaged in late afternoon skirmishes. Lieutenant Henry W. D. Denne, writing about his 'baptism', described the men as 'perfectly steady', but Lieutenant Heywood W. Seton-Karr observed their relief whenever the artillery retaliated, 'as it proved demoralizing to be shelled without firing a shot in return'. He also thought that his men entertained 'a great dread of cavalry even when they are only Bedouins' ${ }^{16}$ 
The Gordons had followed the advanced party from Malta, finding the heat no worse than at Malta, with the agreeable sea breeze and opportunities to bathe regularly at Ramleh. However Denne was by no means alone in regarding the 'glare very bad indeed'; he referred also to the discomfort occasioned by 'insects you can't imagine' $-1 / 2$ doz. fleas is a moderate bag when you take off your clothes, the flies settle on you all day long \& bite ... They don't settle one at a time but in hundreds. The mosquitos very bad at night. ${ }^{177}$ Soldiers soon found distractions in the nearby towns: 3 Gordons were found drunk on guard from Alexandria and 12 Riflemen were seen lying 'dead drunk' in Ramleh railway station. Deprived of the lash, which had been abolished on active service in 1881, military authorities struggled to respond, the colonel of the Gordons having been initially in favour of shooting the offenders, though he was later content to fine and imprison them with hard labour. ${ }^{18}$

When Wolseley ordered the re-embarking of units at Alexandria, he tried to deceive Arabi that the objective was Aboukir, though he planned to sail through the Suez Canal to Ismailia. As he sought to maintain the utmost secrecy by informing only his chief of staff, Sir John Adye, Denne was certainly perceptive in observing: 'The Guards, 60th \& 46th embarked on Thursday last for Ismailia, it is said. ${ }^{19}$ Secrecy was more apparent on the transports, and as soon as the convoy passed Aboukir, conjecture became rife: 'Fifty different places', recalled a Dundonian Marine, 'were named, supported by as many theories. ${ }^{20}$ Yet the journey through the canal was uneventful, apart from the grounding of the transports, Catalonia and Batavia, after the French authorities refused to provide pilots. The navy soon had control of the waterway, with two small gunboats specially rigged with 'Gatlings ready for action in their tops' and torpedo boats cruising up and down. ${ }^{21}$

Wolseley knew that occupying the Suez Canal was only a temporary expedient, conveniently linking the forces from Britain and the Mediterranean with those of the Indian contingent, and that it was potentially hazardous. As soon as Arabi learnt of the deception, he could cut the supplies of fresh water to Ismailia and Suez, and block the rail link alongside the Sweetwater Canal. ${ }^{22}$ Consequently while the navy was securing the Suez Canal, HMS Seagull and HMS Mosquito carried 200 Seaforth Highlanders from Suez to Shaluf, where some 600 Egyptian infantry guarded the lock gates. In a brief encounter the Egyptians were easily routed and the lock gates closed (as were the gates at Serapeum on the following day). Inevitably a Seaforth Highlander regarded this engagement as not simply a means of ensuring the flow of drinking water to Suez, but an occasion to test 'what kind of stuff they (the enemy) were made of ${ }^{\prime 23}$ 
After the landing at Ismailia on 21 August, Wolseley ordered the seizure of the nearby railway junction at Nifshia by a detachment under Major-General Gerald Graham, VC. As sappers and fatigue parties laboured to expand the dock facilities at Ismailia, unloading stores, horses and ammunition, and repairing rail and telegraph connections, water levels in the Sweetwater Canal began to fall. Local intelligence confirmed that dams had been constructed at Magfar, about 10 miles from Ismailia, and then further inland at Tel el-Maskhuta, where the enemy forces were entrenched in force. Wolseley sent reinforcements to Graham and ordered a westwards advance along the railway line to Magfar. 'It was fearful heavy marching', recalled a corporal with the Army Hospital Corps (AHC), 'it was ankle deep in sand. ${ }^{24}$

Having quickly dispersed the skirmishers at Magfar, Wolseley sought to engage the enemy at Tel el-Maskhuta but the protracted artillery duel, involving two guns of the Royal Horse Artillery (later supported by two Gatling guns), deterred the enemy and prompted a withdrawal. 'For once', wrote a Marine, 'we had nothing more serious to do than watch our artillery shell Arabi's forces out of the village of Tel-el-Mahuta. ${ }^{\prime 25}$ As the Egyptian guns fell silent, three squadrons of Household Cavalry, the 4th and 7th Dragoon Guards, and some mounted infantry followed. A cavalry charge into the large camp at Mahsama was repulsed by heavy fire from artillery and wellentrenched infantry: 'I never expected to come out of that alive', claimed Private Robert Gamble (7th Dragoon Guards), 'the shells were dropping all around us, there was a lot of horses shot, but there was only two men killed. ${ }^{26}$ An artillery bombardment and fire from the mounted infantry prepared the way for a second charge. Trooper T. Gittins (1/Life Guards) described the advance from a walk to a trot and then a gallop: 'The sight was too much for the Egyptian warriors, for they bolted, leaving us in entire possession of the camp baggage, hundreds of arms, and tons of ammunition, seven breech-loading Krupp guns (beautiful weapons) and last, but not least, a train load of stores, etc. (about 80 trucks). ${ }^{127}$ Although another train escaped, a detachment of 4th Dragoons moved ahead to seize Kassassin Lock on 26 August, enabling Graham's Brigade to occupy the Lock area on the same day. His forces were now within striking distance (some 7 miles) of the main Egyptian entrenchments at Tel-el-Kebir.

Soldiers realised the risks that Wolseley had taken by advancing so rapidly ahead of his transport and supplies. The Guards and the DCLI, who followed as reinforcements in the heat of the day $(24$ August), suffered acutely. Many men fell out on the line of march, water-carts broke down and the guardsmen could not be prevented from drinking polluted water. 'All day', bemoaned a Scots Guardsman, 
'we toiled through the burning sand, our tongues parched with heat and thirst. ${ }^{128}$ The 'Dukes' at least found a field of melons and so were able to slake their thirst, while the sick toll among the Scots Guards grew alarmingly 'after drinking bad water from the swamp after the march .... ${ }^{29}$

Lieutenant Charles Balfour (1/Scots Guards) deplored the 'disgraceful' lack of medical stores as the Guards had 'no provision for the wounded'. Admittedly the Foot Guards with a royal duke, the Duke of Connaught, in command, were not exposed in the front line (and so grumbled about the lack of action) $;^{30}$ but those in range of the Egyptian gunnery regarded it as highly accurate. As shells with percussion fuses burrowed into the sand on impact, casualties were kept to a minimum, but when a direct hit shattered the leg of a Life Guardsman, the bearer recounted: 'We had to carry him about five miles back to camp, and we were all parched with thirst, and could not get a drop of water . . I fell down twice, and could scarcely get up again. I passed dozens of men lying down exhausted from thirst, crying for water. And then we got nothing to eat for two days. ${ }^{.31}$

Throughout the early advance from Ismailia, medical support remained problematic. Working in single-lined tents Dr Alex S. Rose struggled in the intense heat and the recurrent sandstorms and with the all-pervading flies, as wearing veils was 'not always convenient when we had our medical duties to perform'. He despaired of the water from the canal, the smell and taste of which was 'more easily ... imagined than described', and of the bread which was 'anything but good'. Even worse, he could not find any horses to carry the hospital stores: 'Unfortunately, the transport service had broken down, the result being that we were much hampered in all our movements, and sometimes were left quite helpless. ${ }^{132}$

At least those who reached the Egyptian camps at Tel-el-Maskhuta and Mahsama found provisions, clothing and tents in abundance. At the former, a Dundonian Marine regarded the 'biscuits and tents left by Arabi's troops' as 'very acceptable, the heat being overpowering'. In Mahsama, the Marine wrote, 'we got a fresh supply of camels, all their tents, and plenty of rice, flour, onions, beans, biscuits, and tinned soup ... without Arabi's stores we should have been absolutely starving'.33 The men needed all their energy as they had to dredge numerous corpses (both men and animals) from the canal, breach both dams across the canal (particularly arduous tasks), and remove a major blockage from the railway. Further forward, soldiers constructed entrenchments to protect their exposed position at Kassassin. ${ }^{34}$

On 28 August Arabi Pasha challenged Graham's weak brigade at Kassassin which comprised Marine Artillery, small detachments of 
mounted infantry and the 4th Dragoon Guards, the DCLI and the York and Lancaster Battalions, a troop of 7th Dragoon Guards and two 13pounders (another two were soon sent forward). After a preliminary cavalry charge failed, the Egyptians launched a major infantry assault in three lines, with massive reserves and sixteen cannon. Sergeant Philip, who was in the firing line of the 'Dukes', remembered opening fire 'with a vengeance' from within 900 yards and, after several hours of continual firing, suffering a severely bruised shoulder from the recoil of his rifle. Like others he lauded the achievements of the Marine Artillery, who had mounted one of the captured Krupp guns on a couple of trucks and continued firing long after the horse artillery. ${ }^{35}$

Although Graham's force held its position, brought up reinforcements and saw the enemy retire, the 'moonlight charge' by the Household Cavalry from the right flank turned the repulse into a rout. The cavalry, as Trooper Gittins recalled, had already been called out 'in the heat of the day' to wait for hours in support before returning to camp. ${ }^{36}$ When summoned again, they marched for 5-6 miles until they encountered the enemy's fire. Thereupon, as Lieutenant-Colonel the Hon. Reginald Talbot (1/Life Guards) recorded,

General [Drury] Lowe shortly ordered our guns to unlimber and reply, and the 7th Dragoon Guards to clear the front of our guns, which they did by retiring, making us the first line. The Household Cavalry continued to advance at a walk, when in a moment became visible a white line of infantry in our immediate front, which opened a tremendous fire upon us. Not a moment was to be lost: 'Form front in two lines!' 'Draw swords!' 'Charge!' and we were upon them ... We rode them down in solid rank; but, as they dispersed, we opened up and pursued. They fell like ninepins. ${ }^{37}$

Troopers appreciated that the proximity of the initial encounter had served them well: 'They opened a terrific fire on us at a very short distance', wrote Gittins, 'and lucky for us it was a short one, for they invariably fire high. ${ }^{138}$ Life Guardsmen recounted vicious hand-to-hand fighting, with Trooper Browning claiming that he had decapitated two of the enemy before he himself fell unconscious. ${ }^{49}$ Some found the aftermath an appalling spectacle: 'It was a ghastly sight', recalled Private $H$. Tripper (7th Dragoon Guards), 'to see the enemy's dead lying about in the moonlight', while Private Richard Williams (AHC) observed 'some fearful sights among the wounded' ${ }^{40}$ None of the cavalrymen mentioned charging the enemy's guns, so vindicating the official historian's review of the battle as distinct from contemporary mythology. ${ }^{41}$

On the following day four companies of Marines and a cavalry escort toured the battlefield, finding large quantities of ammunition and sev- 
eral mutilated corpses of cavalrymen. These findings only added to their sense of enmity and the desire to attack Arabi, a prospect made more feasible by the arrival of the first train bringing supplies to Tel-elMaskhuta on 28 August. ${ }^{42}$ The railway company under Major Wallace, $\mathrm{RE}$, had had to repair 230 yards of track from Ismailia to Magfar and bring engines from Suez to Ismailia (as they could not be unloaded at Ismailia) before they could send even one engine along the line. By 31 August they sent a train to Kassassin, and increased the number of trains to 2 per day from 1 September, increasing to 4 per day from 7 September. The engineers also established telegraphic connections between Ismailia and Tel-el-Maskhuta by 31 August and between Ismailia and Kassassin on the following day. As supply boats began to operate beyond Magfar on 2 September, stores accumulated rapidly and more units were pressed forward. ${ }^{43}$

By 8 August a Marine recorded that the Kassassin camp now included 'the Royal Irish (18th); Duke of Cornwall's (46th); York and Lancaster (84th); 3rd Battalion King's Own Rifles (60th); West Kent (50th); Marine Artillery; Marine Light Infantry; and about 2000 cavalry'. In a nearby camp, he added, the Bengal Lancers appeared and 'it was a grand sight to see them, with gay pennons on their lances ...'.44 Stores were now plentiful but the numbers suffering from dysentery, diarrhoea and fever rapidly grew, including medical staff such as Dr Rose. Fortunately many of these illnesses proved transitory, but soldiers 'were getting sick of this place' and wanted to take the offensive, especially as an armoured train had now appeared. ${ }^{45}$

Early on the morning of 9 September Arabi launched another assault on Kassassin, with some 8,000 men, supported by twenty-four guns. Outpost patrols of the 13th Bengal Lancers detected the advance and raised the alarm at about 6.45 a.m. While the Indian Cavalry Brigade sought to delay the Egyptians, Graham prepared a counter-offensive with his Marines and Riflemen along the line of the canal and railway. He had the DCLI and Royal Irish in support, with the Yorks and Lancs ready to counter any move from the northern sandhills, and cavalry on the right to thwart any flanking movements. The infantry pressed forward, as Marling recounted, 'by short rushes of from 50 to 100 yards' and maintained 'a tremendous musketry fire on them', ${ }^{46}$ but the artillery duel was once again decisive. Initially the Egyptian gunners sustained a heavy and accurate bombardment: 'shells were flying about like hailstones', recalled a corporal of the Engineers ${ }^{47}$ and twice the engineer sections at the extreme front had to vacate their positions. Direct hits, as seen by Sapper Powell, could be devastating - one Rifleman lost both legs - but many shells buried themselves in the sand: as Lieutenant-Colonel Kendal Coghill (19th Hussars) observed, 'Their 
artillery fire is very good, but bursting of shells bad. ${ }^{48}$ Once the British gunners limbered up and advanced, they wrecked the range-calculations of their Egyptian counterparts and opened up an effective counter-battery fire. By 9 a.m. the infantry began to advance and within an hour-and-a-half the combined British force had driven the Egyptians from the field, capturing 40,000 rounds of ammunition and three guns. They pursued the enemy to within 5,000 yards of the entrenchments at Tel-el-Kebir. ${ }^{49}$ As many soldiers had rushed into battle without breakfast and even with unfilled water-bottles, the Marines and Riflemen had many exhausted men, with several cases of sunstroke, when they returned to camp. ${ }^{50}$

Wolseley had halted the pursuit, preferring to assemble his full army for a pre-dawn assault on Tel-el-Kebir (to minimise casualties and so ensure that he could follow up via Belbeis and Zagazig to seize Cairo). He now brought forward the Guards Brigade, the remaining artillery and cavalry, and the four battalions of the Highland Brigade that had languished on ships off Ismailia since 1 September. They had disembarked only to undertake fatigues, and on the 4th the Camerons had received a welcome draft of reservists ( 3 officers, 12 non-commissioned officers, 3 drummers and 150 privates); but these reservists, contrary to official claims, came from different regiments. Captain and Adjutant Kenneth S. Baynes recorded: 'Amongst them were a few old 79th men, but the majority were from the 93rd, 91st, and other regiments. ${ }^{.51} \mathrm{On}$ the 9 September the brigade began its march at 3.30 p.m. - 'the hottest part of the day', as bitterly remembered by a Yorkshireman in the Black Watch. ${ }^{52}$ With cavalry on one flank and artillery on the other, the Gordons led the march, followed by the Camerons, Highland Light Infantry (HLI) and then the Black Watch. During the first day men sank to their ankles, sometimes their knees, in soft sand, ${ }^{53}$ struggling through the dust to cover 6 miles by sunset. The camp site, as recalled by the Camerons' Quartermaster John Ainslie, had 'nothing to be seen to the front, right or left but a sea of sand. Behind us the tall masts of the transports rose like a forest out of gathering gloom. ${ }^{154}$ Many never appreciated the view as they had fallen out along the line of march and had to catch up by morning. Some officers of the Black Watch were less than candid in claiming that 'very few' or 'some twenty or thirty of our men fell out', whereas private soldiers reckoned that 'about 100 of ours' succumbed. Lieutenant-Colonel Duncan Macpherson later conceded that 'the men were as game as possible, but one day 150 fell out from exhaustion, and one died ${ }^{\prime} .^{55}$ The brigade continued to suffer from the lack of food and shelter during the next two days. Lieutenant Henry H. L. Malcolm (Camerons) claimed that 'another 200 men fell out' on the second day, 'principally from the 75th', before reaching Mahsama 
where the 'stink was excessive' from the rotting Egyptian corpses. ${ }^{56}$ Seton-Karr admitted that sixty-five Gordons had fallen out on 10 September, and that everyone was relieved to reach Kassassin on the following day, where tents had been brought up by train and the men could eat, rest and recuperate. ${ }^{57}$

By 12 September 17,401 British and Indian officers and men, with 61 guns and 6 naval Gatlings, were ready for the assault. After several days' reconnaissance and gathering evidence from spies, Wolseley and his staff had studied the enemy's defences, manned by 20,000 soldiers and seventy-five guns, and observed the laxity of their pre-dawn watch. His plan of maximising surprise by a silent evening march over the 7 miles to Tel-el-Kebir, with unloaded rifles, had an immediate appeal for Highlanders such as Drummer Bogle (1/Black Watch). The Highland Brigade would lead the charge (flanked by Graham's Brigade to the right and the Indian contingent to the left) and it would 'be done in the old Scotch style - by the bayonet', with no firing until inside the entrenchments. ${ }^{58}$ The men were to carry 100 rounds of ammunition, one day's rations (not two as often claimed) and water bottles filled with tea. ${ }^{59}$ With each battalion marching slowly in two lines, in halfbattalion columns of double companies, they bivouacked for an hourand-a-half at Ninth Hill, where a rum ration was issued to widespread approval. ${ }^{60}$

At 1.30 a.m. the march resumed, utilising telegraph poles laid out over 1,000 yards from the hill, and with Lieutenant Rawson, RN, directing the Highlanders by the stars. Private George Bedson (Black Watch) recalled the 'grand sight to see the two lines advancing in the night; they looked like walls moving ${ }^{\prime}{ }^{61}$ Apart from a drunken private of the HLI, who was quickly suppressed, the sound of the march was also memorable: 'the monotonous tramp', wrote Captain Baynes, 'the sombre lines, the dimly discerned sea of desert, faintly lighted by the stars, were at once ghastly and impressive ${ }^{\prime} .^{62}$ So deep was the silence that when Quartermaster Ainslie with his water carts and pack mule fell behind, he could detect the sound only by listening, ear to the ground, and so hearing 'a murmur like the sea breaking on the shore to my right' ${ }^{63}$ When clouds concealed the stars, the two wings of the Highland Brigade turned inwards and virtually faced each other, but the alignment was restored and just before dawn the brigade found itself about 200 yards from the Egyptian lines. One shot from the enemy was followed by others 'until the whole horizon' seemed to a Black Watch bandsman 'one mass of flame'. ${ }^{64}$ The Highlanders, who were 600 yards ahead of Graham's Brigade, were so close that most of the fusillade passed harmlessly overhead. 'As soon as they opened fire', added Sergeant Charles Riley (Camerons), 'we 
fixed bayonets, and with a good ringing British cheer we charged the trenches' ${ }^{6}{ }^{65}$

An Egyptian officer admitted that the surprise was complete, and that their guns had been sighted for a range of 2,000 yards:

Instead of 2,000 yards, they must have been 200 off. We fired, but most of our shots must have gone over their heads. Almost at the same moment ... they were scrambling over us, first over our right [where the Highlanders attacked] and then rolling down the line like a wave. We never expected a war like this. Our soldiers stood fire at a distance very well . . . but these men came close up to us and the only way to save life was to run away. ${ }^{66}$

Soldiers' memories of the battle, which lasted barely an hour, were perforce limited. As for the Highlanders, who were unsupported for the first 10-15 minutes, they had the experience of plunging into the 5foot-deep ditch with perpendicular sides and then scrambling up a parapet on the other side. Private Donald Cameron /Cameron Highlanders) was the first man up and the second killed as the Camerons and Gordons were the first into the enemy's trenches. 'We were mixed up', recorded Seton-Karr in his diary, '75th and 79th in inextricable confusion, but keep advancing after the flying masses, while those in the rear drive their bayonets through those the front men have shot down. ${ }^{167}$ On the right of the line, where the Black Watch had to cut steps with their bayonets in the 14-foot-high embankment, Private Donald Campbell (Black Watch) characterised 'our men' as 'half-mad to see their comrades falling before they were able to strike a blow; and whenever they got within reach of the enemy they fought like lions' ${ }^{68}$ On the left the 2/HLI attacked a five-gun battery protected by a formidable ditch and suffered the heaviest casualties of any Highland battalion. 'There were cross fires in all directions', wrote LieutenantColonel Abel Straghan, and the artillery fire had a 'demoralising' effect until his men worked round to an easier ditch on the left and climbed into the redoubt. ${ }^{69}$

Soldiers of every rank described their near escapes, or, in some cases, their multiple injuries. They praised the achievements of fallen comrades, such as Sergeant-Major John McNeill (Black Watch), who led his men over the parapet before being shot in the thigh, stomach and groin. ${ }^{70}$ They acknowledged the havoc caused by cross-fire from the shelter trenches in the rear, with the Camerons having to turn a Krupp gun on the enemy, but they persevered with their bayoneting. As Bandsman George Paterson (Black Watch) observed: 'You should have seen the faces the poor wretches put on as the bayonet was driven into them. It is a sight I shall never forget all my life. ${ }^{71}$ They were grateful, 
too, when the horse artillery appeared and the infantry helped to lift the guns over the parapet. Viscount Fielding (RA, N/2 battery) then galloped down 'one side of a long line of entrenchment', periodically stopping to enfilade the enemy while the Black Watch ran along the other side of the trenches: 'We went on like this down the whole of the line, nearly two miles', sometimes firing case at only 200 yards. $^{72}$ While N/2 went on to shell Arabi's train, the following battery had, according to one of its gunners, 'great practice; but it was cruel butchery. A shell from my left gun took a man's head clean off, and then went on, burst, and killed five more. After four or five rounds from each gun, we limbered up, and advanced to Arabi's camp' ${ }^{73}$

Graham's Brigade made rapid progress in its sector. Although the Marines and the infantry had to cross a longer fire zone, most of the Egyptian fire was aimed too high. The Yorks and Lancs company of Sergeant McChesney

took no notice of being a support, what we wanted was to be up in the front ... we took no notice of any orders, but fixed our bayonets, and off we went like wild men, charging and shouting till we were hoarse again. The scene was awful when we got up to the trenches, as it was every man for himself. However, it did not last long, it was all over in about half an hour. ${ }^{74}$

The Royal Irish Fusiliers advanced in short rushes, and, unlike the Royal Marines, fired several volleys before charging the entrenchments, where Sergeant R. D. Healey found large numbers of Arabs either killed or wounded:

We bayoneted all who came in our way. You should have heard the yells of the beggars as we 'let daylight into them'. It was something terrible. The majority retreated to another ridge, where they again opened fire, but a few shots, a cheer, and charge, had the effect of making them move at a pace unusual with their habits. Then their retreat became more general ... We followed them for a couple of miles, halting ultimately to let the Artillery and Cavalry perform their part of 'not a bad day's work'. ${ }^{75}$

South of the canal the Indian contingent and the Naval Brigade moved against the well-fortified right flank, where the Seaforths advanced towards trenches filled with Egyptians and four 7-pounder guns. A non-commissioned officer described how the Seaforths responded in kind to the Egyptian volleys and made 'great gaps in the rebel ranks. For over half-an-hour this work continued, the enemy gradually retiring and we occupying their trenches. One gallant comrade near me fell dead, being shot through his Afghan medal.' Following Brigadier-General Oriel V. Tanner and a young subaltern, they 
charged the enemy's guns, precipitating a wholesale retreat: 'All ran but the gunners, who, to their credit be it said, remained to the last and were cut down. ${ }^{176}$ Another Seaforth veteran reckoned: 'It was about the shortest fight that ever I had, and as cheap a medal that ever an army got. ${ }^{177}$

The cavalry poured through on both sides of the canal, albeit at different rates. While a squadron of the 6th Bengal Cavalry tried to cut off fugitives from the southern side of the canal, the main Indian Brigade advanced from the north ahead of the Heavy Cavalry Brigade which, as Coghill asserted, 'had not calculated on such a sharp \& decisive business so crept slowly round the enemy's right'. Meanwhile Coghill's squadron of the 19th Hussars galloped through the centre, making straight for the railway where he claimed to have blocked the departure of three trains by 'dropping a camel' across the tracks. Although there were competing claims for the disruption of the rail network, Coghill is correct in maintaining that the rapidity and depth of the cavalry pursuit, with the hussars chasing for about 12 miles, 'completely routed and demoralised' the enemy, ${ }_{18}^{78}$ and secured both Belbeis with its telegraph office and Zagazig later in the day.

For the Foot Guards and other units coming up in reserve, the brevity of the engagement was an intense frustration. As Balfour reflected, 'we never did anything during the fifty minutes the action lasted', claiming that 'the Egyptians made such a poor showing no support was required by the first line' ${ }^{\prime}{ }^{79}$ Most soldiers agreed, one Black Watch officer even asserting: 'How they can run, those Arabs, and what a capital 'fox' they would make for a paper chase at home!' $;{ }^{80}$ but they exempted the Egyptian gunners, who died at their posts, and the black Sudanese soldiers. As Major Robert Coveny (Black Watch) acknowledged: 'The Soudan warriors, thick-lipped negro-typed creatures in light blue tunics, died very game, their bodies lying perfectly thick in the trenches. ${ }^{181}$

Many were appalled by the aftermath of the battle in which a total of perhaps 2,000 Egyptians died as well as 57 British soldiers (with another 382 wounded and 30 missing). Private James Judson, another Yorkshireman in the Black Watch, found the scene 'heartrending', that is 'the sight of the dead and dying, who lay all around us - an old man here, a young man there, or a riderless horse galloping madly on in the confusion' ${ }^{82}$ One of his comrades described the canal as 'full of dead and dying horses, camels, and men. Confusion reigned everywhere, our cavalry firing and mowing them down, the artillery stretching dozens at a time. We captured about 50 tons of ammunition at the station, and stores of every description, including horses and camels - in fact, all his camp equipage. ${ }^{183}$ The wounded were in a desperate state: many cried 
out for water and some buried their heads in the sand to cool themselves. A Crieff soldier, in trying to help, filled his water bottle from the canal 'with water that you would not wash the door-step with, as it was thick with blood and mud' ${ }^{84}$ Several chronicled the dangers of moving over the battlefield, when some Egyptians either feigned injury or turned on those who gave them water, and, as soon as they passed, shot them in the back. ${ }^{85}$ None of these incidents deterred soldiers from the wholesale looting of Arabi's camp: 'Lots of our fellows', admitted Quartermaster Ainslie, 'picked up valuable articles ... and near the station were immense stores of all sorts, and they all fell into our hands, along with a great number of baggage animals and cavalry horses ${ }^{\prime}{ }^{86}$

The AHC, as Private Richard Williams recalled, struggled to cope: 'We could see some of the firing, but, after a time, our work commenced. The wounded began to be carried in and oh! to see some of the poor fellows smothered in blood and arms and legs blown to pieces, and they were groaning and crying for water, which was something dreadful to hear.' After treating the British wounded, he confirmed that the AHC spent several days assisting the Egyptian wounded, whose numbers overwhelmed their services. Within a few days they had 300 Arabs under treatment and were losing 'five or six a day', with the flies and mosquitoes tormenting all concerned. ${ }^{87}$ On 17 September an AHC corporal led a party of eleven men and six carts across the battlefield, where some dead lay unburied and the 'stench was fearful'. They collected another thirty-six Arabs, whose 'wounds were in a fearful state $^{\prime .88}$

Wolseley's priority had been to complete the dispersal of Arabi's army and reach Cairo as quickly as possible. Accordingly the Indian contingent marched on to Zagazig (15 miles from Tel-el-Kebir) by the afternoon of the battle, while the mounted infantry and 4th Dragoon Guards rode ahead to Belbeis. After a short rest they proceeded to Cairo, arriving at the Citadel at 5 p.m. on 14 September, where Arabi and 8,000 soldiers surrendered to 120 men from the mounted infantry and dragoons. The Foot Guards arrived by train on the following day: as Private Geddes (Scots Guards) informed his parents, 'We marched triumphantly into this city ... amidst the cheers of the Europeans and all the native Christians, who were intoxicated with delight at our success $^{\prime}{ }^{89}$ Many Egyptian soldiers were keen to ingratiate themselves, with Sapper Powell finding them to 'take a great interest in trying to catch and repeat different English words, and . . very anxious to show their good feeling, bringing us oranges, dates, sugar, cigarettes, etc..$^{90}$ Arabi's several hundred prisoners were particularly glad to see the Guardsmen and recount their tales of torture and food deprivation: the 
Guards fed the prisoners and put 'the officer (a Bey) who carried out Arabi's orders ... in irons' ${ }^{\prime 91}$

Although soldiers were restricted in their movements, they were impressed by Cairo and the nearby pyramids. 'Without doubt', wrote Bandsman Paterson, 'Cairo is as pretty a city as ever I saw. The streets are lined with tall, shady trees on each side, while the houses (in the principal part of the city) are magnificent. ${ }^{192}$ Soldiers were not so impressed by the quarters that they had to inhabit. Both the Citadel and the Kasr-el-Nil barracks were found utterly squalid and verminous. Sergeant Charles Spraggs (Scots Guards) recorded how a great many men preferred to sleep at night on the parade ground to avoid 'the large number of Bugs and insects'. ${ }^{93}$ Several palaces were found to be in similar condition - 'dusty and filthy in the extreme' to quote Dr Rose ${ }^{94}-$ so that many units remained in encampments on the outskirts of Cairo or near Zagazig and Belbeis before quarters were established on the island of Bulak. Conditions were grim: the Black Watch spent eight days outside Belbeis with no tents, sleeping in their kilts and consuming nothing but hard biscuits, preserved meat and muddy water..$^{95}$ The number of those sick rapidly mounted, with the Gordons, after twelve days at Tantah, forced to send off 5 officers and 140 men for medical treatment. ${ }^{96}$ Once again the medical authorities struggled initially: Dr Rose found himself 'very much overworked' and had only 4 orderlies to treat 245 patients sent in on a single day ${ }^{97}$ Patients suffered from fever, ophthalmia and diarrhoea, with Sergeant Spraggs finding the medical remedies for severe diarrhoea somewhat drastic, namely 'some Castor oil and oppium [sic] to see if that will do me any good'.$^{98}$

Soldiers wrote many of their letters as they languished in encampments after Tel-el-Kebir, and some moved beyond descriptive narratives to praise the tactical planning of Wolseley, especially the night march prior to battle. A Scots Guards private called it 'a splendidlyplanned attack', while a corporal of the Royal Engineers regarded Sir Garnet 'as a fine General; his Generalship was unsurpassable'. ${ }^{99}$ Yet Wolseley's reports on the battle proved profoundly contentious. As the telegraph unit, with 10 miles of cable, had followed the infantry across Tel-el-Kebir to establish a telegraph office at the railway station, Wolseley was 'greatly pleased' to send news of the victory with unprecedented rapidity. ${ }^{100}$ Rumours quickly circulated that his despatch had heaped praise on the Guards under their royal duke (so appeasing the Queen), on the achievements and discipline of the young soldiers (so endorsing the Government's army reforms) and on the efficiency of the support services (so concealing the main shortcomings of the campaign). Privately, Wolseley, who expected (and received) a peerage and a pension for his services, insisted: 'The government owe me a 
great deal .... The battle of Tel el Kebir has been worth millions to Gladstone's administration', while the Queen's 'only sympathies \& solicitude are for Her own selfish self and Her family'. ${ }^{101}$

The Marines and Highlanders were incensed. Whereas the former, who suffered the heaviest casualties of any unit at Tel-el-Kebir, regarded themselves as 'second to none', the latter considered that they did 'the whole of the work'. Both deplored plaudits for the supporting units; 'The Guards, etc.', wrote a Black Watch sergeant, 'were - I don't know where; anyhow they did nothing' and the 3/60th, in the rear of the Gordons, were in Denne's words 'not so swift to the front that they trod our heels off'. ${ }^{102}$ Aggrieved soldiers believed that Wolseley had exploited his powers of censorship: 'the correspondents', asserted a Black Watch private, 'are not allowed to send home any news but what is approved of by Sir Garnet Wolseley'. ${ }^{103}$ Soldiers had mixed feelings towards the war correspondents: they had enjoyed their company socially but criticised the risks they took in battle, which could bring down fire on themselves, and deprecated some of their reporting. If Lieutenant Walter S. Churchward, RA, exaggerated in claiming that 'newspaper men are all liars \& wrote absurd accounts in the papers especially The Times and Standard', soldiers complained in their letters about the failure of the transport and commissariat, aware that the press could not do so. ${ }^{104}$ By 15 October, Denne readily observed: 'The correspondents, now supervision has ceased, are showing up the comm[issaria]t \& hospital defects, all they say \& more is true. ${ }^{105}$

On the issue of whether the campaign vindicated army reforms, as claimed by Wolseley and Childers ${ }^{106}$ opinions divided. While Sergeant Healey agreed that the young soldiers had proved themselves in Egypt, Denne reckoned that the $72 \mathrm{nd}$ (1/Seaforths) were 'a fine regt. of old soldiers \& the smartest I have ever seen ${ }^{\prime}{ }^{107}$ In fact, there was not a sharp gulf between the home- and India-based battalions. Many of homebased units had left behind all soldiers under 20 years of age and most had a nucleus of older or long-service men. ${ }^{108}$ Even more impressive, argued Sergeant-Major Greig, RA, were 'our native Indian troops, strong muscular fellows, and like greyhounds on the leash eager to be at the foe'. ${ }^{109}$ The achievements of all these soldiers were magnified by the incapacity of the Egyptians: as Denne remarked, 'Sir F. Roberts had much greater difficulties to contend with [in the Second Afghan War] \& did much more than Wolseley'. ${ }^{110}$

Most soldiers, though, emerged from the campaign with their sense of self-esteem enhanced. They had overcome natural obstacles and numerical odds, and believed that they had done so in a righteous cause. The chorus of Drummer Bogle's poem 'The Highland Brigade' extolled 
The success to the few, the gallant few,

Of that famous Scottish band,

Who are ready to fight in the cause of the right,

And the honour of their native land. ${ }^{111}$

Soldiers appreciated the profusion of medals and promotions awarded (not only a campaign medal with a clasp for those at Tel-el-Kebir but the Khedive's bronze star and 165 Orders of the Osmanieh and the Medjidieh from the Sultan of Turkey). They relished, too, the parade in review order before the Khedive on 30 September. As the culminating spectacle of the campaign, Sergeant Philip maintained that the purpose 'was to overawe and instil into the dull native mind the overpowering strength of the nation they had been opposing . . . [and] to give the ruler and his subordinates a sight of the army that beat and sent their countrymen flying from the trenches at Tel-el-Kebir in such a short time on that eventful morning'. ${ }^{112}$

\section{Notes}

1 Brooks, Long Arm of Empire, pp. 171-80.

2 Emery, Marching Over Africa, pp. 187-8. The profusion of letters from the Black Watch may reflect its prominence in the assault on Tel-el-Kebir and the fact that it was the only unit in the Highland Brigade that had joined the expedition directly from Britain, and so had the more immediate ties with family and friends at home.

3 H. C. G. Matthew, Gladstone, 1875-1898 (Oxford: Clarendon Press, 1995), pp. 130-7; A. Schölch, "The "Men on the Spot" and the English Occupation of Egypt in 1882', Historical Journal, 19:3 (1976), 773-85.

4 Duke of Cambridge to Childers, 13 July 1882 in Childers, Life and Correspondence, vol. 2, pp. 91-2; see also M. J. Williams, 'The Egyptian Campaign of 1882', in Bond (ed.), Victorian Military Campaigns, pp. 243-78.

5 Colonel J. F. Maurice, Military History of the Campaign of 1882 in Egypt (London: HMSO, 1887), pp. 6-9; Wolseley to Childers, 29 July 1882, in Childers, Life and Correspondence, vol. 2, pp. 99-100.

6 BWA, 0203/1, A. V. Barwood, diary, 1 December 1882, p. 1.

7 Private Macaulay, 'With the Guards in Egypt', in Small (ed.), Told from the Ranks, pp. 44-60; see also Ward, 'The Scots Guards in Egypt', 80-1.

8 'The Battle of Tel-el-Kebir: Letter from Another Crieff Soldier', Strathearn Herald, 21 October 1882, p. 2, and 'Letter from an Invergordon Young Man in Egypt', Invergordon Times, 13 September 1882, p. 3.

9 'Letter from an Invergordon Young Man', p. 3.

10 'Letter from a Northampton Private', Northampton Mercury, 9 September 1882, p. 6.

11 Macaulay, 'With the Guards in Egypt', p. 46; 'Death of a Lichfield Man', Lichfield Mercury, 8 September 1882, p. 8; 'Letter from an Invergordon Young Man', p. 3.

12 'Letter from a Northampton Private', p. 6; 'The War in Egypt. Letter from a Son of the Rock', Stirling Observer, 28 September 1882, p. 4.

13 'Letter from a Wolverhampton Man in Egypt', Midland Counties Express, 26 August 1882, p. 7.

14 'Death of a Lichfield Man', p. 8; see also Col. W. L. Vale, History of the South Staffordshire Regiment (Aldershot: Gale \& Polden, 1969), p. 187.

15 J. Philip, Reminiscences of Gibraltar, Egypt, and the Egyptian War, 1882 (Aberdeen: D. Wyllie \& Son, 1893), pp. 41-2. 
16 GHM, PB64/1, Maj. H. W. Denne to his father, 22 August 1882 and PB228, Lt H. W. Seton-Karr, diary, 20 and 21 August 1882.

17 GHM, PB64/1, Denne to his father, 22 August 1882, and PB228, Seton-Karr, diary, 19, 20 and 29 August 1882; see also BWA, 0203/1, Barwood, diary, 1 December 1882, p. 6.

18 GHM, PB64/1, Denne to his father, 22 August 1882, and PB228, Seton-Karr, diary, 19, 20 and 29 August 1882.

19 GHM, PB64/1, Denne to his father, 22 August 1882; see also Williams, 'The Egyptian Campaign of 1882 ', p. 259.

20 'A Dundee Soldier's Description of the Recent Fighting', Weekly News, 23 September 1882, p. 7.

21 Ibid.; see also Ward, 'Scots Guards in Egypt', 87.

22 Wolseley to Childers, 29 July 1882, in Childers, Life and Correspondence, vol. 2, pp. 99-100.

23 'Battle for Tel-el-Kebir: Letter from Another Crieff Soldier', p. 2.

24 'A Maidstone Soldier at the Seat of War', Kentish Gazette, 24 October 1882, p. 3.

25 'A Dundee Soldier's Description of the Recent Fighting', p. 7.

26 'Letters from Ludlow Men Serving in Egypt', Hereford Journal, 7 October 1882, p. 3.

27 'Letter from a Staffordshire Soldier', Staffordshire Advertiser, 16 September 1882, p. 2.

28 'A Dundee Soldier at Tel-el-Kebir', Weekly News, 7 October 1882, p. 7.

29 Philip, Reminiscences, p. 55; Ward, 'The Scots Guards in Egypt', 91.

30 Ward, 'Scots Guards in Egypt', 91 and 93.

31 'A Maidstone Soldier at the War', p. 3.

32 'Letter from a Townsman in Egypt', Brechin Advertiser, 10 October 1882, p. 3.

33 'A Dundee Soldier's Description of the Recent Fighting', p. 7.

34 Ibid.; 'A Dundee Soldier at Tel-el-Kebir', p. 7; Macaulay, 'With the Guards in Egypt', pp. 48-9.

35 Philip, Reminiscences, pp. 69, 72; 'Letter from a Staffordshire Soldier', p. 2.

36 'Letter from a Staffordshire Soldier', p. 2; see also Memoirs of Sir Hugh McCalmont, p. 215.

37 'Letter from a Local Officer of the Guards in Egypt', Midland Counties Express, 30 September 1882, p. 7.

38 'Letter from a Staffordshire Soldier', p. 2.

39 Ibid., and 'A Guardsman's Recollection of the Great Cavalry Charge', Lancaster Guardian, 9 September 1882, p. 4.

40 'A Stafford Trooper's Experiences in Egypt', Lichfield Mercury, 13 October 1882, p. 7.

41 Maurice, Military History of the Campaign of 1882, p. 64; D. Featherstone, Tel ElKebir 1882: Wolseley's Conquest of Egypt (London: Osprey, 1993), pp. 56, 61.

42 'A Dundee Soldier's Description of the Recent Fighting', p. 7.

43 Maj. A. W. Mackworth, 'The Field Telegraph Corps in Egypt', and Capt. S. Smith, 'Diary of Work Performed by the 8th Company, R.E., in Egypt', REJ, 12 (1 December 1882), 269-72, and 13 (1 January 1883), 4-8; see also Williams, 'The Egyptian Campaign of $1882^{\prime}$, pp. 267-70.

44 'A Dundee Soldier's Description of the Recent Fighting', p. 7.

45 Ibid.; 'Letter from a Townsman in Egypt', p. 3; Ward, 'The Scots Guards in Egypt', 94.

46 GRO, D 873/C110, Marling to his father, 10 September 1882.

47 'Letters by a Soldier to his Crieff Friends', Strathearn Herald, 14 October 1882, p. 2.

48 NAM, Acc. No. 7112/39/4, Coghill MSS, Lt-Col. K. Coghill to Flo, 10 September 1884; see also 'An Oxonian in Egypt', Abingdon and Reading Herald, 28 October 1882 , p. 6, and 'Letter from the Hon. Rupert Leigh', Coventry Herald and Free Press, 6 October 1882, p. 4.

49 Philip, Reminiscences, pp. 80-2.

50 GRO, D873/C110, Marling to his father, 10 September 1882, and 'The Marines at 


\section{THE VICTORIAN SOLDIER IN AFRICA}

Tel-el-Kebir', Weekly News, 14 October 1882, p. 7.

51 Queen's Own Highlanders Collection (QOHC), Capt. K. S. Baynes, Narrative of the Part Taken by the 79th Queen's Own Cameron Highlanders in the Egyptian Campaign, 1882 (private, 1883), p. 12.

52 'A Yorkshireman's Account of the Capture of Tel-el-Kebir', (Batley) Reporter, 7 October 1882 , p. 3.

53 Ibid.; 'Letter from the Black Watch', Bridge of Allan Reporter, 21 October 1882, p. 2.

54 'Soldiers' Letters', Scotsman, 6 October 1882, p. 5.

55 Compare 'Royal Highlanders $(42 \mathrm{ND})^{\prime}$, Broad Arrow, 7 October 1882, p. 502, with 'The Highland Brigade', Scotsman, 11 October 1882, p. 7; 'March of the Highland Brigade from Ismailia to the Front', Nairnshire Telegraph, 4 October 1882, p. 4; 'A Dundee Highlander at Tel-el-Kebir', Weekly News, 14 October 1882, p. 7; 'A Yorkshireman's Account of the Capture of Tel-el-Kebir', p. 3.

56 'Extracts from the Diary of Lieut. H. H. L. Malcolm, 79th, Q. O. Cameron Highlanders, during the Egyptian War, 1882', 79th News, 202 (April 1933), 150-5.

57 GHM, PB 228, Seton-Karr, diary, 31 August 1882.

58 'The Black Watch at Tel-el-Kebir', Stirling Observer, 12 October 1882, p. 2; see also Featherstone, Tel E1-Kebir, p. 72.

59 'Highland Brigade', p. 7; 'The Storming of Tel-el-Kebir', Strathearn Herald, 7 October 1882, p. 2; 'A 42D Man at Tel-El-Kebir', Kinross-shire Advertiser, 28 October 1882 , p. 3.

60 GHM, PB 64/2, Denne to his father, 20 September 1882; BWA 0204, Lt-Col. Coveny, 'Letters from Egypt and the Sudan', 28 September 1882, p. 7; 'A 42D Man at Tel-ElKebir', p. 3.

61 'A Private Soldier's Description of the Battle of Tel-el-Kebir', Staffordshire Advertiser, 30 September 1882, p. 6.

62 QOHC, Baynes, Narrative of the Part taken by the 79th, p. 19; see also Lt-Col. L. B. Oatts, Proud Heritage: The Story of the Highland Light Infantry, 4 vols. (London: Thomas Nelson, 1959), vol. 2, p. 363.

63 'Soldiers' Letters', p. 5.

64 'A Dundee Highlander at Tel-El-Kebir', p. 7.

65 'Hairbreadth Escapes of a Cameronian [sic] Highlander', Sheffield Daily Telegraph, 5 October 1882, p. 3.

66 'A Native Account of the Battle of Tel-el-Kebir', Staffordshire Advertiser, 7 October 1882, p. 6.

67 GHM, PB 228, Seton-Karr, diary, p. 7; see also 'A Perthshire Hero at Tel-el-Kebir', Kinross-shire Advertiser, 7 October 1882, p. 3.

68 'A Rothesay Man at the Charge at Tel-el-Kebir', Rothesay Express, 18 October 1882, p. 3; see also 'The Battle of Tel-el-Kebir (By a 42D Highlander)', (Edinburgh) Daily Review, 5 October 1882, p. 5.

69 'More About Tel-el-Kebir: Interesting Letter to Herefordshire People', Hereford Times, 21 October 1882, p. 2; see also 'A Glasgow Highlander's Description of Telel-Kebir', Glasgow News, 10 October 1882, p. 5, and Oatts, Proud Heritage, vol. 2, pp. 363-6.

70 'Battle of Tel-el-Kebir (By a 42D Highlander)', p. 5; 'Black Watch at Tel-el-Kebir', p. 2; 'Extracts from the Diary of Lieut. H. H. L. Malcolm', 153-4; 'Royal Highlanders', p. 502; 'A Soldier's Letter', Scotsman, 13 October 1885, p. 5.

71 'The Late Lieutenant G. Stirling', Strathearn Herald, 21 October 1882, p. 2; QOHC, Baynes, Narrative, p. 21.

72 'The Royal Artillery at Tel-el-Kebir', Bradford Observer, 10 October 1882, p. 6.

73 'A Private Letter from Egypt', Hastings and St Leonards News, 6 October 1882, p. 3

74 'Letter from a Derbyshire Man', Derbyshire Times, 7 October 1882, p. 5.

75 'The Battle of Tel-el-Kebir - Letter from a Blackburn Soldier', Blackburn Times, 7 October 1882, p. 6; 'The Services of the Royal Marines in Egypt', Western Morning News, 29 September 1882, p. 3.

76 'A Soldier's Experiences at Tel-el-Kebir', Banffshire Journal, 10 October 1882, p. 3. 
77 'Battle of Tel-el-Kebir: Letter from Another Crieff Soldier', p. 2.

78 NAM, Acc. No.. 7706/14, Coghill MSS, Coghill to Flo, 14 September 1882; see also The Marquess of Anglesey, A History of the British Cavalry 1816 to 1919, 8 vols (London: Leo Cooper, 1973-97), vol. 3, pp. 301-2.

79 Ward, 'The Scots Guards in Egypt', 99.

80 'Highland Brigade', p. 7.

81 BWA, 0204, Coveny, 'Letters from Egypt and the Sudan', p. 8; see also 'The Battle of Tel-el-Kebir. Letter from an Invergordon Young Man', Invergordon Times, 11 October 1882, p. 2; 'Black Watch at Tel-el-Kebir', p. 2; 'Storming of Tel-el-Kebir', p. 2.

82 'A Soldier's Account of Tel-el-Kebir', (York) Evening Press, 16 October 1882, p. 3; see also Williams, 'Egyptian Campaign of 1882', p. 274.

83 'Battle of Tel-el-Kebir (By a 42D Highlander)', p. 5.

84 'Storming of Tel-el-Kebir', p. 2.

85 'Soldiers' Letters', p. 6; 'At Tel-el-Kebir', Kentish Chronicle, 4 November 1882, p. 2; 'Battle of Tel-el-Kebir - Letter from a Blackburn Soldier', p. 6; 'Conduct of Our Soldiers at Tel-el-Kebir', Colchester Chronicle, 21 October 1882, p. 3.

86 'Soldiers' Letters', p. 6; see also 'Highland Brigade', p. 7.

87 'Letters from Ludlow Men Serving in Egypt', p. 3.

88 'A Maidstone Corporal at the Seat of War', p. 3.

89 'The War in Egypt', Bridge of Allan Reporter, 14 October 1882, p. 2.

90 'An Oxonian in Egypt', p. 6.

91 'The Torturing of Prisoners in the Citadel', Scotsman, 7 October 1882, p. 7; Ward, 'Scots Guards in Egypt', 101.

92 'Late Lieutenant G. Stirling', p. 2; see also 'Letter from Another Crieff Soldier', p. 2.

93 NAM, Acc. No. 7706/14, Sergeant C. Spraggs, diary, 17 September 1882.

94 'Letter from a Townsman in Egypt', p. 3; see also NAM, Acc. No. 7003/25, Churchward MSS, Lt W. S. Churchward to Annie, 25 September 1882; 'The Naval Brigade in Egypt', Hampshire Telegraph and Sussex Chronicle, 21 October 1882, p. 8.

95 'A 42D Man at Tel-el-Kebir', p. 3.

96 GHM, PB 64/3, Denne to his father, 15 October 1882.

97 'Letter from a Townsman in Egypt', p. 3.

98 NAM, Acc. No. 7706/14, Spraggs, diary, 6 October 1882; see also 'Letter from a Knighton Man', Hereford Times, 21 October 1882, p. 2.

99 'The Duke of Connaught's Pluck', Strathearn Herald, 21 October 1882, p. 2, and 'Letters by a Soldier to His Crieff Friends', p. 2; see also Philip, Reminiscences, p. 98; 'Services of the Royal Marines in Egypt', p. 3.

100 'Letters by a Soldier to His Crieff Friends', p. 2 and Mackworth, 'The Field Telegraph Corps in Egypt', 271.

101 'Battle of Tel-el-Kebir: Written Despatch from Sir Garnet Wolseley', Derby Mercury, 11 October 1882, p. 3; RPLM, Wolseley MSS, W/P.11, Wolseley to Lady Wolseley, 21 and 28 September 1882, ff. 21 and 23.

102 'Slight to the Marines', Weekly News, 21 October 1882, p. 7; 'Letter from a Crieff Soldier in Egypt', Strathearn Herald, 28 October 1882, p. 2; 'Battle of Tel-el-Kebir (By a 42D Highlander)', p. 5; GHM, PB 64/2, Denne to his father, 20 September 1882.

103 'Letter from a Crieff Soldier in Egypt', p. 2; see also 'Slight to the Marines', p. 7.

104 NAM, Acc. No. 7003/25, Churchward to Annie, 25 September 1882; see also Evening Standard, 6 October 1882, p. 8; Ward, 'Scots Guards in Egypt', 92; 'Battle of Tel-el-Kebir: Letter from an Invergordon Man', p. 2; Philip, Reminiscences, pp. 56-7.

105 GHM, PB 64/3, Denne to his father, 15 October 1882.

106 'Mr Childers and the Army', Cornubian and Redruth Times, 27 October 1882, p. 3.

107 'Battle of Tel-el-Kebir - Letter from a Blackburn Soldier', p. 6; GHM, PB 64/3, Denne to his father, 15 October 1882.

108 The Black Watch had 300 men of over 6 years' service; the Gordons, 370 over 24 years; the Camerons, 460 over 24 years; and the men of the HLI had an average of about 8 years' service: 'The "Young Soldiers" at Tel-el-Kebir', Manchester Guardian, 12 October 1882, p. 8. 


\section{THE VICTORIAN SOLDIER IN AFRICA}

109 'Letter from Egypt', East of Fife Record, 22 September 1882, p. 3; see also 'A Dundee Soldier's Description of the Recent Fighting', p. 7.

110 GHM, PB 64/4, Denne to his father, 1 May 1883.

111 'Black Watch at Tel-el-Kebir', p. 2.

112 Philip, Reminiscences, p. 103; on medals, see GHM, PB 64/3, Denne to his father, 15 October 1882;'A Dundee Highlander at Tel-el-Kebir', p. 7 and Featherstone, Tel El-Kebir, p. 91. 